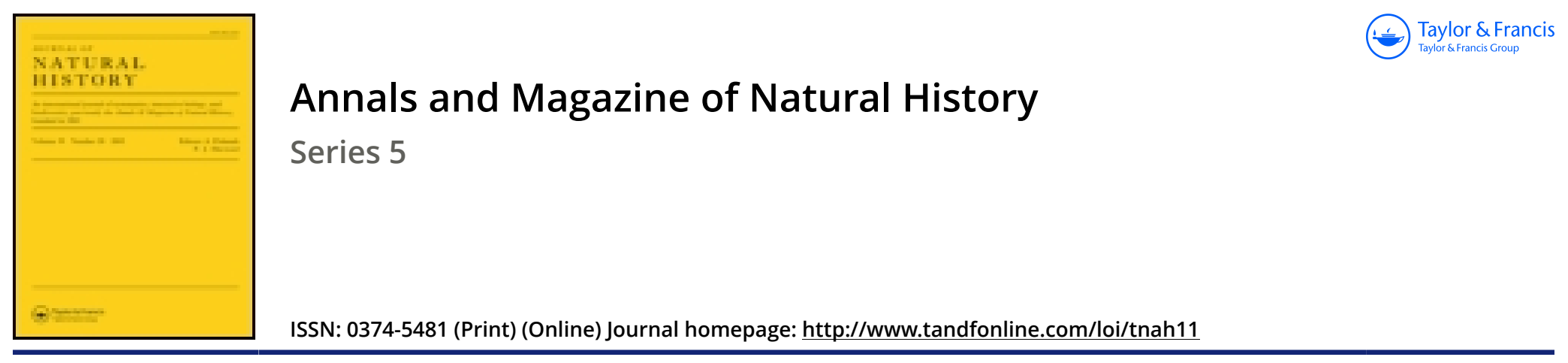

\title{
XXXII.-Contributions to micro-Palæontology.-On Stenopora Howsii, Nich., with notes on Monticulipora? tumida, Phill., and Remarks on Tabulippora Urii, Young
}

\author{
H. Alleyne Nicholson M.D. D.Sc.
}

To cite this article: H. Alleyne Nicholson M.D. D.Sc. (1883) XXXII.-Contributions to microPalæontology.-On Stenopora Howsii, Nich., with notes on Monticulipora? tumida, Phill., and Remarks on Tabulippora Urii, Young , Annals and Magazine of Natural History, 12:71, 285-297, DOI: $10.1080 / 00222938309459632$

To link to this article: http://dx.doi.org/10.1080/00222938309459632

$$
\text { 曲 Published online: } 09 \text { Oct } 2009 .
$$

Submit your article to this journal ए

$$
\text { Џll Article views: } 3
$$

View related articles $\asymp$

Citing articles: 1 View citing articles 주 


\title{
THE ANNALS
}

\section{AN D \\ MAGAZINE OF NATURAL HISTORY.}

[FIFTH SERIES.]

No. 71. NOVEMBER 1883.

\begin{abstract}
XXXII.-Contributions to Micro-Palceontology._On Stenopora Howsii, Nich., with Notes on Monticulipora? tumida, Phill., and Remarks on Tabulipora Urii, Young. By H. Alleyne Nicholson, M.D., D.Sc., Regius Professor of Natural History in the-University of Aberdeen.
\end{abstract}

[Plate X.]

1. Stenopora Howsii, Nich.

IN a recent visit to Northumberland I was fortunate enough to obtain a considerable number of specimens of the singular Stenopora Howsii, Nich., of which I had previously published a short provisional description and figures, based upon a magnificent example in the cabinet of Mr. Richard Howse, F.G.S. (see 'The Genus Monticulipora,' p. 83, fig. 12, 1881). Having, therefore, now had the opportunity of examining a large series of specimens in all stages of growth, and also of preparing a number of thin sections, I purpose giving on the present occasion a fuller description of the characters of this remarkable type.

As regards its essential specific characters the corallum of Stenopora Howsii is ramose, with subcylindrical or flattened branches, which are mostly from $\frac{1}{4}$ to $\frac{1}{2}$ inch in diameter. Ann. \& Mag. N. Hist. Ser. 5. Vol. xii. 
Am" \& Mar Nat. Hist. S. 5. Vol IR. P7. X.

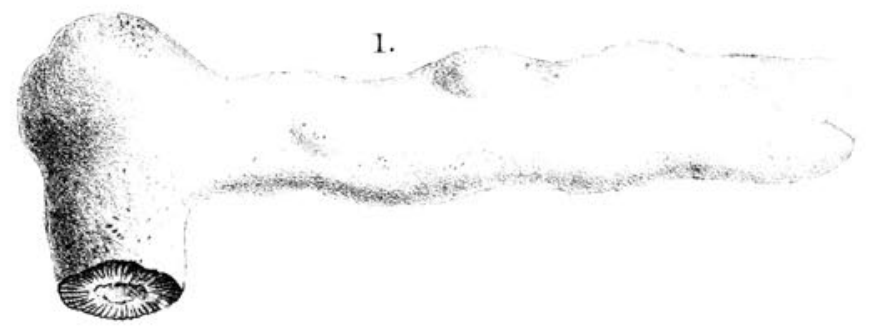

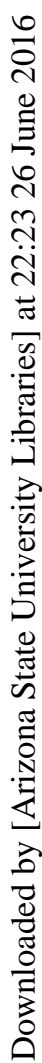
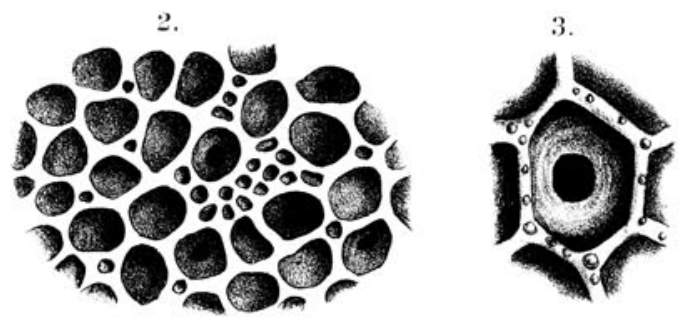

4.
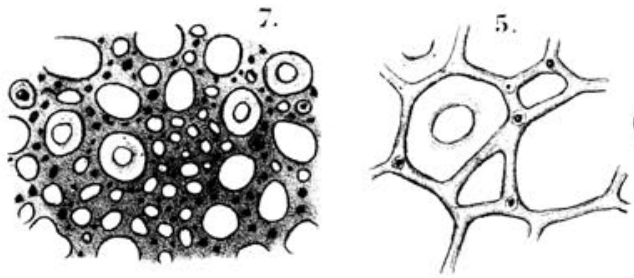

8.
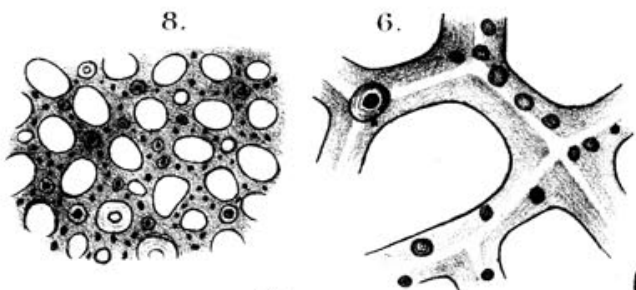

10.
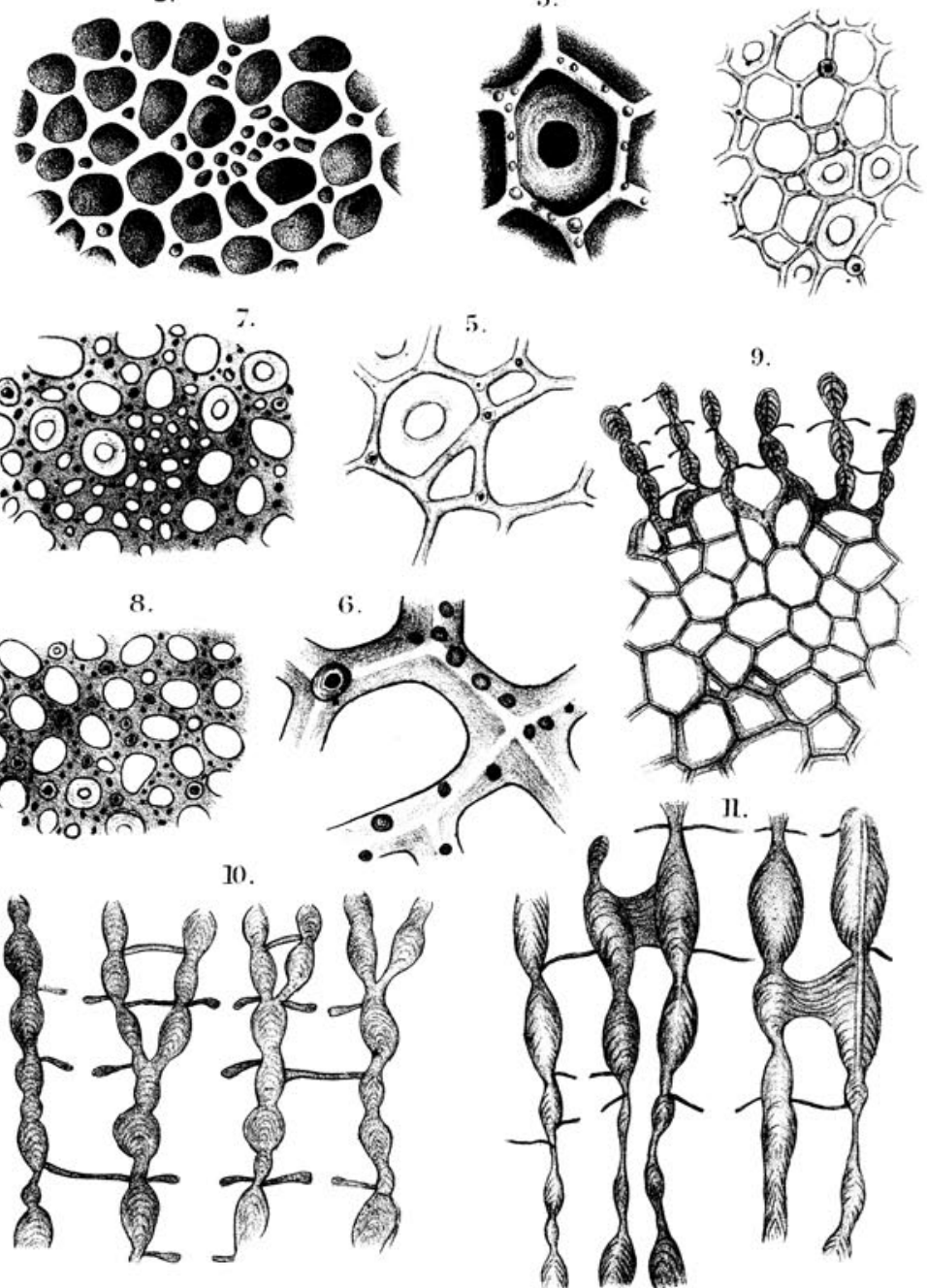

9.

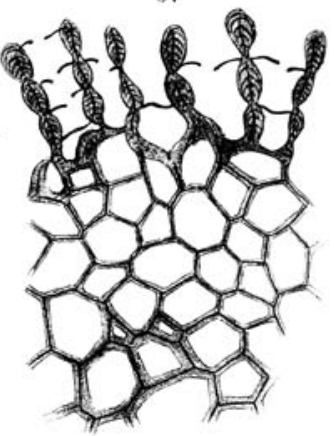

. 
The walls of the corallites are completely amalgamated, and the calices are polygonal, comparatively thin-walled, and (including the wall) mostly about $\frac{1}{6} \delta$ inch in diameter, clusters of slightly larger tubes, intermixed with small tubuli, occurring here and there. Minute interstitial tubes are present at the angles of junction of many of the large corallites, or are collected into stellate groups or "maculæ." The walls of the corallites are marked with conspicuous periodic enlargements or annulations, and the tabulæe are usually perforated by a central aperture. Mural pores have not been detected.

As regards external characters, British examples are always ramose, the branches being usually compressed or flattened, though sometimes quite cylindrical, and often exhibiting slight tumid enlargements at intervals. The stems vary in diameter from 2 to 7 lines; and the Arctic specimens, which I shall subsequently describe as forming a distinct variety, are still more massive, or even become sublobate. The calices are polygonal and decidedly thin-walled (especially as compared with the calices of the associated Monticulipora? tumida, Phill.). In size they are mostly from $\frac{1}{60}$ to $\frac{1}{50}$ inch in diameter; but not uncommonly groups of corallites slightly larger than the average may be present here and there, and there is always a variable number of small interstitial tubuli. These latter are not only disseminated among the larger tubes, but are commonly aggregated into star-shaped "maculæ" (Pl. X. fig. 2), which may be a line or more across, but are not, so far as I have seen, elevated above the general surface. At other times the tubuli occupy irregular and narrow linear tracts. The surface is not markedly roughened or spinulose, though all well-preserved examples exhibit under the microscope many small blunt tubercles on the lips of the calices. Lastly, many of the calices show the marked feature that their floor is formed by a tabula which is perforated by a central aperture (Pl. X. figs. 2 and 3 ).

As regards internal structure, the corallites exhibit marked differences according as they are examined in the axial region or in the periphery of the branches. Thus, in the axial region. the corallites are at first vertical, but soon bend gradually outwards, and they are here always polygonal and mostly thin-walled (Pl. X. fig. 9). The lines of demarcation between contiguous tubes have not yet been obliterated, and when the tubes are thickened (as they sometimes are) the thickening is uniform and not intermittent. Moreover the tabulæ of the axial region are always very sparsely developed, and, when present, are always imperforate and complete.

On the other hand, in the final or peripheral portion of 
their course the corallites assume their mature characters, and now exhibit the features peculiar to Stenopora. As regards their direction, they are now bent outwards approximately at right angles to the axis of the branch, and their walls are now thickened periodically by annular enlargements, which are placed at corresponding levels in contiguous tubes. Hence, in the broken ends of the branches, the corallites show a highly characteristic beaded appearance; and in thin sections (fig. 1, C) the walls are seen to have a marked moniliform structure, narrow unthickened segments alternating with annular thickenings or nodes.

Fig. 1.
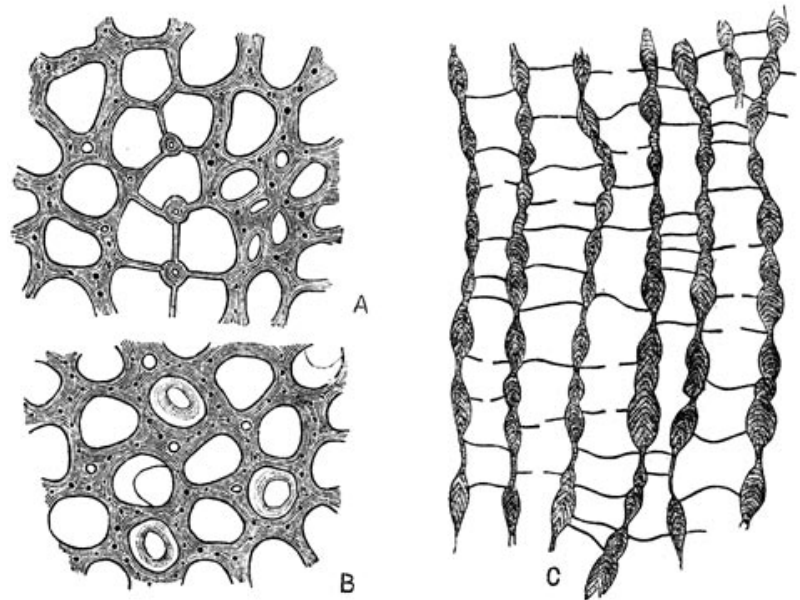

Stenopora Howsii, Nich., from the Carboniferous rocks of Redesdale. A. Tangential section traversing in part the unthickened segments of the tubes. B. Tangential section traversing the thickened segments of the tubes. C. Portion of the peripheral region of a transverse section, showing the thickenings of the walls and the perforated tabulæ. All the figures are enlarged about eighteen times.

As regards the minute structure of the walls of the corallites, the thickened nodes are formed (as in the species of Stenopora generally) by the growth of successively superimposed thin layers of sclerenchyma, each layer forming a kind of conical cap, as seen in section (Pl. X. fig. 10). The walls of adjacent corallites are apparently so amalgamated and fused together that no traces can, as a rule, be detected of the original boundary-lines of the separate tubes. In some cases, however, in tangential sections it is possible, by means of a careful management of the light, to recognize the original 
polygonal lines of demarcation of the different corallites; but even in this case such lines only appear as clear spaces (Pl. $\mathrm{X}$. fig. 6). In the structure of the wall, therefore, $S$. Howsii agrees with such forms as Stenopora tasmaniensis, Lonsd., and differs from such as S. ovata, Lonsd., and S. crinita, Lonsd., the boundary-lines in these latter species remaining permanently recognizable as distinct dark lines marking off the originally polygonal corallites *.

The tabulæ of the peripheral region of the corallum are exceedingly characteristic, the great majority (possibly all) being perforated by a central oval, or subcircular, or reniform aperture, the structure, however, being wholly unlike that which characterizes the genus Prasopora, Nich. \& Eth. As seen in tangential sections (Pl. X. figs. 4, 7, and 8) the tabulæ appear as circular ledges, surrounding the visceral chambers, and each perforated by a central aperture, the immediate margin of which is somewhat thickened. As seen, on the other hand, in longitudinal or transverse sections (Pl. X. figs. $9 \& 10$ ), the tabulæ present themselves as so many pairs of short, nearly horizontal, or somewhat deflexed processes, the free ends of which, where they abut upon the central aperture, are slightly thickened or bulbous. Some of the tabulæ appear to be complete and to pass completely across the visceral chambers of the corallites. It is probable, however, that all the tabulx in the peripheral region are really perforated, and that the apparent completeness of some of them is merely due to the fact that the line of section at that particular point traversed the visceral chambers excentrically, and therefore did not pass through the central perforations of the tabulæ. In any case, the tabulæ mostly spring from the unthickened segments of the corallites, and are mostly about $\frac{1}{10 \sigma}$ inch apart. It is also the last-formed tabula which appears as the perforated diaphragm at the bottom of so many of the calices.

Finally, in tangential sections the appearances presented vary according as the section passes through the tubes at the level of their thickened nodes, or at that of the unthickened internodes, the resulting differences being usually observable in different portions of the same slice. Thus, if the section should traverse the unthickened segments of the corallites (as seen in the lower part of fig. $1, \mathrm{~A}$, and in Pl. X. figs. 4 and 5), the tubes appear to be comparatively thin-walled and approximately polygonal, and there are comparatively few and

* The occurrence of such a well-marked difference of structure as that above noted, in species otherwise so closely allied, would lead us to suppose that it is, perhaps, hazardous to lay great stress upon the amalganation or non-amaIgamation of the walls of the corallites as a point of generic distinction. 
small dark spots marking the presence of spiniform processes or small tubuli. Very commonly, however, there are seen at the angles of junction of the corallites large, round, very thickwalled tubes, each with a central dark spot or a minute median opening. It is difficult to be certain what these circular thick-walled tubes may be; but they are very characteristic of most tangential sections of $S$. Howsii, and they perhaps represent a special series of corallites. On the other hand, if the section traverse the thickened nodes of the corallites (as in fig. 1, B, and in Pl. X. figs. 7 and 8), the tubes appear to be thick-walled, and we observe in general the following objects:-(1) the oval or circular apertures of the ordinary corallites, some of these being occupied by the ringlike perforated tabulæ; (2) the apertures of small interstitial tubuli, either scattered here and there (Pl. X. fig. 8) or aggregated into "maculæ" (Pl. X. fig. 7) ; (3) numerous irregularly distributed dark spots in the walls of the corallites, which often exhibit a minute clear spot in the centre, and which are doubtless the sections of hollow spines; and (4) large circular thick-walled tubes, such as have been previously alluded to, which present a central dark spot or clear space, and usually a well-marked dark margin (Pl. X. fig. 6).

As regards the affinities of Stenopora Howsii, it is most nearly allied to $S$. tasmaniensis, Lonsd.; but the latter is easily distinguished by the smaller number and much larger size of its spiniform tubes, and by the fact that the tabula of the peripheral region are fow in number, and, so far as my observations have gone, imperforate. The form, however, which it is most difficult to separate from $S$. Howsii is that which has been generally recognized as Monticulipora (?) tumida of Phillips; but before discussing this point I may briefly describe a remarkable form of $S$. Howsii from the Arctic regions.

\section{Stenopora Howsii, var. aretica, Nich.}

There exist in the magnificent collection of the British $\mathrm{Mu}$ seum several specimens of a large Stenopora from the Carboniferous rocks of Feilden Isthmus, which were collected in the Nares expedition. By the kindness of my friend Dr. Henry Woodward, F.R.S., I have been permitted to examine these specimens, and at once satisfied myself as to their substantial identity with the Stenopora Howsii of the Carboniferous rocks of Northumberland. They exhibit, however, certain subordinate points of distinction from the British types, and $I$ think it best therefore to mark the existence of these by the addition of a varietal name. 
S. Howsii, var. arctica, is a larger and more massive form than the normal examples of the species, but its general mode of growth is the same, and there is no essential difference as regards their general structure. Tabulæ are, however, less abundantly developed in the peripheral region of the corallum (Pl. X. fig. 11), and are therefore separated by wider intervals. On the other hand, there is a specially extensive development of the curious thick-walled tubes which I have described as occurring in the normal form of $S$. Howsii. These remarkable structures are best observed in tangential sections, whether these traverse the corallum at the level of the unthickened segments of the corallites (fig. 2, A) or at that of the thickened nodes (fig. 2, B). In longitudinal

\section{Fig. 2.}
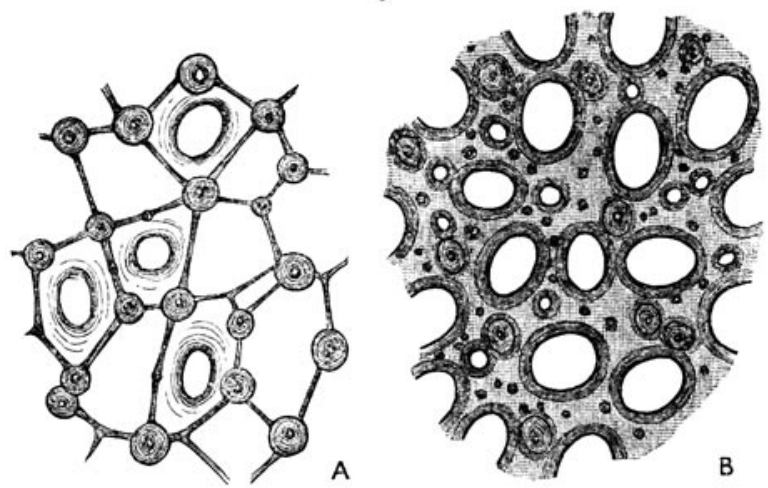

A. Part of a tangential section of Stenopora Howsii, var. arctica, taken at the level of the unthickened segments of the tubes, enlarged twenty-four times. B. Another part of the same section, taken at the level of the thickened parts of the tubes, similarly enlarged.

sections (Pl. X. fig. 11) the same structures appear as tubes running in the thickness of the walls of the ordinary corallites.

While these singular tubes are remarkably abundant, the interstitial tubuli which are such a striking feature in thenormal form are here somewhat diminished in number. The chief point, however, by which S. Howsii, var. arctica, is distinguished from the type of the species is that the walls of the corallites are decidedly thicker and the visceral chambers more contracted than in the latter, while each visceral chamber is surrounded by a ring-like investment of fibrous sclerenchyma (fig. 2, B).

Formation and Locality. The type of the species occurs in 
the Carboniferous rocks of Redesdale, in Northumberland (coll. Richard Howse and H. A. Nicholson). The Arctic specimens (var. arctica) are from the Carboniferous rocks of Feilden Isthmus (lat. $82^{\circ} 43^{\prime}$ N.), and were collected by Capt. Feilden, as naturalist to the Nares expedition (coll. Brit. Mus.).

\section{Notes on Monticulipora? tumida, Phill.}

The general characters and minute structure of the form which I regard as being the Calamopora tumida of Phillips have been previously described by me ("The Genus Monticulipora,' p. 120). After an examination of an enormous number of additional specimens, I have only little of structural importance to add to the description formerly given; but I should wish to make some remarks as to the affinities and synonymy of the species.

Monticulipora? tumida, Phill., is an essentially dendroid species, but, like other ramose forms, it often begins its existence in the shape of a thin crust growing upon the stem of a Crinoid or some similar object. The stems are mostly between 1 and 2 lines in diameter, but may reach at least 3 lines in diameter. The calices are rounded, oval, or subpolygonal, with very thick walls, their actual apertures being round or oval and mostly between $\frac{7}{90}$ and $\frac{1}{80}$ inch in diameter. The lips of the calices are raised into prominent rims, which slope down by a deeply concave edge to the margin of the actual visceral chamber, thus giving rise in some cases to the appearance of perforated diaphragms at the bottom of the calices; but I am satisfied that this is the true explanation of the appearances in question. The prominent intercalicine ridges always support, in unrubbed examples, a row of prominent blunt spines, which can sometimes be observed to open by distinct circular apertures, and which give to the surface a characteristic rough or spinulose aspect and feel. Lastly, minute corallites or interstitial tubes are commonly developed at the angles of junction of the larger corallites, or are aggregated to form distinct maculæ.

With regard to the internal structure of the corallum, tangential sections (fig. 3, A) show that the walls of the corallites are completely amalgamated in the peripheral region, the conjoint walls being usually about $\frac{1}{120}$ inch across, while the visceral chambers average about $\frac{1}{80}$ inch in diameter. The visceral chamber of each corallite is surrounded by a thickened fibrous layer, and the interspaces between the corallites are filled with clear sclerenchyma, traversed by rows of darkcoloured hollow spines. Minute corallites or tubuli are also 
developed in variable amount, and often appear in clusters. Tangential sections taken a little below the surface show, further, that the corallites gradually become less and less thickened, and more and more polygonal in outline, while traces of the original lines of demarcation between adjacent tubes can be made out, and the spiniform tubules gradually disappear. In the axial region of the corallum, as shown in longitudinal or transverse sections (fig. $3, \mathrm{~B}$ ), the corallites, finally, become completely separate, having now thin walls and a polygonal outline.

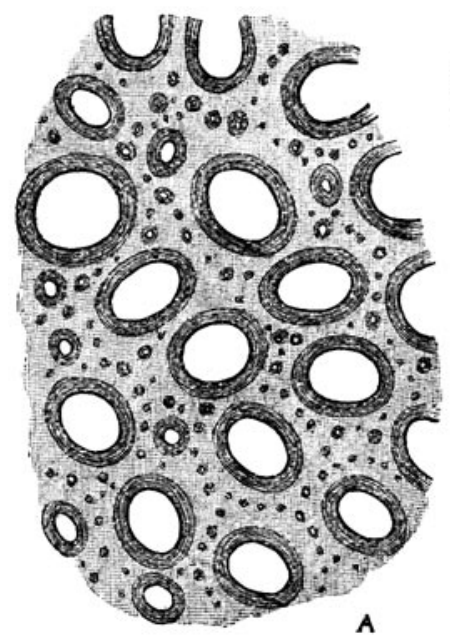

Fig. 3.

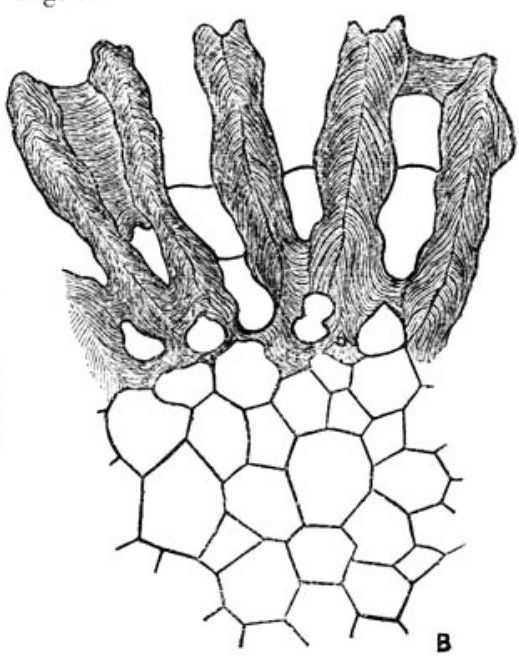

Monticulipora? tumida, Phill, from the Carboniferous rocks of Redesdale, Northumberland. A. Part of a tangential section, enlarged twenty-four times, showing the large and small corallites, and the rows of interstitial spiniform tubules. B. Part of a transverse section, enlarged twenty-four times, showing the polygonal and thin-walled axial tubes and the thickened walls and complete tabulæ of the peripheral portions of the corallites.

The only two remaining structural points to notice concern the nature of the tabulæ and the thickening of the walls of the mature corallites. As to the first of these two points, it is quite certain that the tabulæ are essentially and habitually complete and imperforate (fig. 3, B). In no single longitudinal or transverse section have $I$ ever detected an incomplete tabula, and out of a large number of tangential sections I have only once met with an instance of a perforated tabula, and then only in one or two corallites.

As to the second point, the walls of the corallites in the peripheral region of the corallum are invariably greatly thick- 
ened (fig. 3, B); and they sometimes exhibit a sort of periodic variation in the amount of this thickening, causing the walls to be thicker in some parts than in others. In no case, however, does the wall come to consist of a series of unthickened segments separated by thickened annular nodes; so that neither in rough fractures nor in longitudinal sections do we find the walls of the corallites exhibiting a moniliform or beaded aspect.

This last point brings us to consider for a moment the generic position of this species. There can be no doubt that in its general characters, Monticulipora? tumida, Phill., makes a very close approach to such species of Stenopora as $S$. tasmaniensis, Lonsd., and, still more, S. Howsii, Nich. This was formerly pointed out by myself; and, after a renewed investigation, I can only repeat that "so far as our present knowledge goes, the only points which would definitely separate $M$. tumida, Phill., from Stenopora are, that it certainly shows no traces of the peculiar moniliform and periodic thickening of the walls of the corallites which is characteristic of the latter genus, and that there is no evidence as to the presence of mural pores" ("The Genus Monticulipora,' p. 124). The existence or non-existence of mural pores may be left out of account, however, as these structures are so difficult of detection; so that the structure of the wall alone remains to separate $M$. tumida from Stenopora. It must be added, however, that this last point is one so essentially characteristic of the genus Stenopora, Lonsd., that it would seem impossible to include under this name any type which did not exhibit this peculiar feature as regards the mature corallites.

The species from which it is most difficult to separate $M$.? tumida is Stenopora Howsii, and I may briefly summarize the chief points which distinguish them.

(a) Dimensions of corallum.-The corallum of M.? tumida is in general markedly smaller than that of $S$. Howsii, branches of the former being most commonly about a line and a half or two lines in diameter, whereas the stems of the latter average about four lines in diameter. Still, large stems of $M$.? tumida cannot by this character alone be separated from small stems of $S$. Howsii.

(b) The calices of $M$. ? tumida are markedly thickened and usually circular or oval, whereas those of $S$. Howsii are comparatively thin-walled and are generally polygonal.

(c) The lips of the calices in $M$.? tumida carry numerous blunt spines, which in well-preserved specimens terminate in minute circular apertures, and which give to the surface a markedly rough and spinulose aspect. In $S$. Howsii, though 
similar spines exist, they are comparatively small and short, the surface wanting, therefore, the rough appearance which exists in $M$. ? tumida.

(d) The tabulce in the peripheral region of the corallum are few in number in $M$.? tumida, and are almost invariably complete and imperforate. On the other hand, the tabulæ of the same region in S. Howsii are numerous, and are, mostly or wholly, perforated by central apertures. Hence many of the calices in this latter type have their floors formed by one of these perforated tabula.

(e) The walls of the corallites in the peripheral region of the corallum are in $M$. ? tumida greatly thickened, but the thickening is approximately uniform and shows no regular intermissions. In $S$. Howsii, on the other hand, the walls of the corallites in the same region are intermittently thickened, and thus assume a moniliform or beaded structure.

(f) M.? tumida does not appear to possess the singular thick-walled circular tubes which are so commonly developed in S. Howsii at the angles of junction of the normal corallites.

As to the synonymy and nomenclature of $M$.? tumida, a good deal of confusion has been caused by the fact (which I have only recently come to appreciate fully) that $M$.? tumida and $S$. Howsii have hitherto been imperfectly or not at all separated from one another-this being not unnatural when it is remembered that the two commonly occur together and are externally very similar. Hence some observers have either included both types under the name of $M$. tumida, or have founded their descriptions of $M$. tumida upon specimens which really belong to $S$. Howsii.

It is quite clear that Phillips himself included at least two different forms under the name of Calamopora tumida. One form ('Geol. of Yorkshire,' pl. i. figs. 49-51) is almost certainly the form which I have, here and elsewhere, regarded as Monticulipora tumida. Another form (ibid. pl. i. figs. 52, $56,57)$ may be taken, with an equal approach to certainty, to be the type which I have here called Stenopora Howsii. Under these circumstances, considering the very brief nature of the description given by Phillips, it would perhaps have been best to have suppressed the name of "tumida" altogether; but the wide currency which it has acquired renders this impossible. I shall therefore retain it for the species lere so named; and in giving a synonymy of the species I should omit all the figures given by Phillips in plate $i$. of his 'Geology of Yorkshire,' except figs. 49, 50, and 51. 
Again, it is difficult to avoid the conclusion that $\mathbf{M}^{\prime} \mathrm{Coy}$, in his great work (Brit. Pal. Foss. p. 82), applied Phillips's name of "tumida" to the form which I understand to be Stenopora Howsii. This is shown partly by the fact that $\mathrm{M}^{\prime} \mathrm{Coy}$ only refers to one of Phillips's figures, that being fig. 52 (by obvious misprint given as fig. 25), which I regard as a figure of $S$. Howsii; and partly by the fact that his description applies admirably to $S$. Howsii, but not at all to the form which $I$ take as $M$. ? tumida, Phill. Hence, if this view be accepted, the name of Stenopora tumida, $\mathrm{M}^{`} \mathrm{Coy}$, must be omitted from the synonymy of $M$.? tumida, Phill., sp., and nust be given as a synonym of Stenopora Howsii, Nich., as the retention of the specific name of tumida for the latter would lead to hopeless confusion.

It would, further, seem probable that under the name of Chretetes tumidus, Milne-Edwards and Haime included more than one form. The figure which they give in the 'British Fossil Corals' (pl. xlv. fig. 3) is apparently referable to Stenopora Howsii; but they probably had also examined the true $M$. ? tumida; and they certainly included under the same title the wholly distinct type described by De Koninck as Calamopora inflata, and by $\mathrm{M}^{\prime} \mathrm{Coy}$ as Stenopora inflata. It is therefore only in part that Chotetes tumidus, E. \& H., can be quoted as a synonym of Monticulipora? tumida.

Finally, I may just add that I am inclined to think that the form described by Prof. De Koninck as Monticulipora tumida is really quite distinct from either of the British forms. M. De Koninck was good enough to furnish me with authentic specimens of the Belgian type; and though they are unfortunately in a state of preservation which has prevented my making thin sections of them, I have been led to the above conclusion from their general appearance, and especially from the fact that the corallites of the peripheral region are inclined to the surface at a much more acute angle than is the case in $M$. ? tumida or in S. Howsii, while that region of the corallum is itself much more contracted in proportion to the size of the stems.

\section{Remarks upon Tabulipora Urii, Young.}

Since the foregoing was written, I have had the opportunity of reading the interesting paper which Mr. John Young has just published (Ann. \& Mag. Nat. Hist. Sept. 1883, p. 154) upon a Monticuliporoid from the Carboniferous rocks of Scotland, which he identifies with Cellepora Urii, Flem., and places in a new genus under the title of Tabulipora. 
According to Mr. Young, this form is a dendroid coral of the usual type of the Monticuliporoids, but especially distinguished by the nature of its tabulæ. In the axial region the corallites are stated to be without tabula, while in the peripheral region the tabulæ are numerous and are perforated by "roundly crescentic" or "reniform" openings, which are so directed that "the concave edges of the opening in branching specimens is invariably turned towards the lower end of the branches." In longitudinal sections of the corallites the perforated tabulæ are stated to appear as "a series of small thin projecting points with a little rounded knob at their ends." It would further appear from Mr. Young's description that the walls of the corallites are not annulated in the peripheral region, and that mural pores are not present.

The perforated tabulæ render it clear that this form is distinct from that which I regard as M.? tumida, Phill., and it only remains therefore to say a few words as to its relations to Stenopora Howsii. In so doing, the question of mural pores can be left out of account (as not detected in either form), and the only two features of importance which need be discussed are the tabula and the walls of the corallites. As regards $S$. Howsii, it is not uncommon for the central perforations of the tabulæ to have one margin slightly protuberant, and thus to become rudely reniform; but the curved edges of different perforations certainly do not point in any particular direction in any particular specimen, but, on the contrary, point in different directions. Apart from this, however, I cannot regard the mere presence of perforated tabulæ as sufficient to preclude the reference of Tabulipora Urii to the genus Stenopora, Lonsd., since these structures exist in S. Howsii, and probably in other species of Stenopora as well. If, on the other hand, I rightly understand Mr. Young to state that the corallites in the peripheral region in Tabulipora Urii have walls destitute of annular thickenings, then, certainly, this form cannot be referred to the genus Stenopora, since the moniliform or annulated wall is the most essential character of the latter genus.

Apart from the character just mentioned, Tabulipora Urii, Young, would appear to be extremely similar to Stenopora Howsii, Nich., and if they had agreed in the structure of the wall, I should have been disposed to regard them as undoubtedly identical. Should this ultimately prove to be the case, I must frankly admit, however, that $I$ shall not feel inclined to abandon my specific name in favour of that of "Urii," Fleming. Nor, indeed, should I, under any circumistances, regard it as advisable to resuscitate Fleming's species, even if such 
a resuscitation could be effected with the certainty that we had to deal with Fleming's original specimen or specimens. In this repugnance to the revival of a title so defined originally as to be absolutely undeterminable, I think I should not find myself singular, especially when it is recollected that Fleming's entire description ('Brit. Animals,' p. 533) was as follows:-" Cellepora Urii. Branched, round, about a quarter of an inch in diameter, form round.-Millepore, Ure, Ruth. 228, t. xx. f. 1." If, therefore, it should be proved that Tabulipora Urii (as described by Mr. Young) is a good species, it should, in my opinion, stand as $T$. Urie, Young, and not as T. Urii, Flem. It may just be added that even admitting that Ure gave, to begin with, a good figure of his "Millepore," this is not one of the cases in which a figure can be used as a basis for specific identification, since all modern palæontologists would, I think, admit the total inadequacy of a mere figure of the external appearance of a specimen of one of the dendroid Monticuliporoids or Stenoporoids as a guide for specific, or even generic, determination.

\section{EXPLANATION OF PLATE $X$.}

Fig. 1. A fragment of Stenopora Howsii, Nich., of the natural size. From the Carboniferous shales of Redesdale, Northumberland.

Fig. 2. Portion of the surface of the same, enlarged twelve times.

Fig. 3. $\boldsymbol{\Lambda}$ single calice, enlarged twenty-four times, showing a perforated tabula.

Fig. 4. Portion of a tangential section, taken across the unthickened segments of the tubes, enlarged twelve times.

Fig. 5. Part of tho same section, enlarged twenty-four times, showing interstitial spiniform tubes.

Fig.6. Part of another tangential section, enlarged forty-five times, showing the original bounding-lines of the corallites.

Fig. 7. Part of a tangential section, taken across the thickened portions of the corallites, at a point where a "macula" is present, enlarged twelve times.

Fig. 8. Another tangential section, where no "macula" is shown, similarly enlarged.

Fig. 9. Part of the centre of a transrerse section, showing the thin-walled polygonal axial corallites, enlarged twelve times.

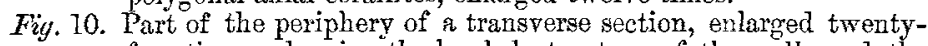
four times, showing the beaded structure of the walls and the perforated tabulæ.

Fig. 11. Part of the periphery of a transverse section of $S$. Howsii, var. arctica, enlarged twenty-four times. 